\title{
Fatty Acid Profiles of Waste Fish Skins and Potential Use for Crackers
}

\author{
Emre YAVUZER \\ Gıda Mühendisliği Bölümü, Mühendislik Mimarllk Fakültesi, Kırşehir Ahi Evran Üniversitesi, 40300, Kırşehir, Türkiye.
}

How to cite: Yavuzer E. (2020). Fatty Acid Profiles of Waste Fish Skins and Potential Use for Crackers. J. Anatolian Env. and Anim. Sciences, 5(4), 527532.

Atıf yapmak için: Yavuzer E. (2020). Atık Balık Derilerinin Yağ Asidi Profilleri ve Krakerlerin Potansiyel Kullanımı. Anadolu Çev. ve Hay. Dergisi, 5(4), $527-532$.

https://orcid.org/0000-0002-9192-713X

*Corresponding author's:

Emre YAVUZER

Department of Food Engineering, Faculty of

Engineering and Architecture, University of

Ahi Ervan, 40300, Kirşehir, Türkiye

凶: emreyavuzer@gmail.com

<emreyavuzer@gmail.com>;MAIL

Mobile telephone : $+90(535) 9653158$

Telephone : +90(386) 2805409

\begin{abstract}
Fish skins, which are usually the result of processing the product, are often seen as waste products. Due to its high commercial value, a large amount of fish skin is revealed during the processing of intensively produced trout, sea bream and sea bass. The aim of this study is to examine the fatty acid profiles of rainbow trout/ Oncorhynchus mykiss (G1), sea bream/ Sparus aurata (G2) and sea bass/ Dicentrarchus labrax (G3) obtained by cultivation and to measure the panelist perceptions of edible crackers obtained from these fish skins by sensory analysis. According to sensory analysis results the G1 group was significantly $(\mathrm{p}<0.05)$ positive separated from the other groups in terms of color, odor, taste and texture parameters. The fatty acid compositions of groups changed from 21.27- 24.59\%, 41.43-45.18\% and 28.06-29.48\% for saturated (SFAs), monounsaturated (MUFAs) and polyunsaturated fatty acids (PUFAs), respectively. The ratio of w6/w3 PUFAs was 1.27 in G1, 1.77 in G2 and 1.71 in G3. Among the analyzed fish species, the highest DHA (C22:6n3) was obtained from G1, with value of $5.86 \%$ while G2 and G3 had 4.09 and $4.14 \%$ of DHA. But EPA was significantly (p>0.05) higher in G2 and G3 groups than G1. The study data found that waste fish skins can be used in making crackers and among the three fish used, the cracker made of trout skin gained sensory appreciation.
\end{abstract}

Keywords: Cracker, fish skin, byproduct, fried skin.

\section{Atık Balık Derilerinin Yă Asidi Profilleri ve Krakerlerin Potansiyel Kullanımı}

\author{
*Sorumlu yazar: \\ Emre YAVUZER \\ Gıda Mühendisliği Bölümü, Mühendislik \\ Mimarlık Fakültesi, Kırşehir Ahi Evran \\ Üniversitesi, 40300, Kırşehir, Türkiye \\ 凶: emreyavuzer@gmail.com \\ Mobile telephone : +90 (535) 9653158 \\ Telephone $\quad:+90(386) 2805409$ \\ Fax $\quad:+90(386) 2805400$
}

Öz: Balıkların işlenmesi sonucu ortaya çıkan balık derileri genellikle atık ürün olarak görülür. Ticari değeri yüksek olması nedeni ile yoğun olarak üretilen alabalık, çipura ve levrek balıklarının işlenmesi sırasında fazla miktarda balık derisi ortaya çıkmaktadır. Bu çalışmanın amacı, yetiştiricilik yolu ile elde edilmiş gökkuşağı alabalı̆̆ı/Oncorhynchus mykiss (G1), çipura/Sparus aurata $(\mathrm{G} 2)$ ve levrek/Dicentrarchus labrax (G3) derilerinin yağ asidi profillerini incelemek ve bu balık derilerinden elde edilen yenilebilir krakerlerin panelist algılarını duyusal analizle ölçmektir. Duyusal analiz sonuçlarına göre G1 grubu renk, koku, tat ve doku parametreleri açısından önemli seviyede $(\mathrm{p}<0.05)$ diğer gruplardan olumlu olarak ayrılmıştır. Grupların doymuş (SFA'lar), tekli doymamış (MUFA'lar) ve çoklu doymamış yağ asitleri (PUFA'lar) sirasıly \% 21.27- 24.59, \% 41.43-45.18 ve \% 28.06-29.48 arasında değişmiştir. w6 / w3 PUFA'ların oranı G1'de 1.27, G2'de 1.77 ve G3'te 1.71 idi. Analiz edilen balık türleri arasında en yüksek DHA (C22: 6n3)\% 5,86 değeriyle G1'den elde edilirken, G2 ve G3\% 4,09 ve\% 4,14 DHA'ya sahiptir. Çalışma verileri atık balık derilerinin kraker yapımında kullanılabileceğini ve kullanılan üç balık içersinde alabalık derisinden yapılan krakerin duyusal açıdan beğeni kazandığı tespit edilmiştir.

$\underline{\text { Anahtar kelimeler: Balık derisi, kraker, yan ürün, kızartılmıș deri. }}$ 


\section{INTRODUCTION}

Aquatic products include important PUFAs for human health such as EPA (eicosapentaenoic acid, C20:5n3) and DHA (docosahexaenoic acid, C22:6n3) and also high level of protein and minerals (Özoğul et al., 2013; Yavuzer, 2018; Zhu et al., 2019). These long-chain PUFAs have great importance for humans to prevent of coronary artery disorders, inflammatory diseases and cancer (Conner, 2000; Giudetti \& Cagnazzo, 2012; La Rovere \& Christensen, 2015; Simopoulos, 1991; Ward \& Singh, 2005). Although DHA is the main part of heart muscles, brain and eye retina (Ward \& Singh, 2005), EPA is also important for brain disorders and cancer treatment (Fenton et al., 2000).

Depending on population growth, there is a trend towards alternative food sources in the world and also sensory flavor is the most important factor in meeting the energy requirements. Therefore it can be difficult to find a healthy and tasty combination of foods. Fish meat is the major sources of PUFA for the human diet but different parts of fish species have variable fatty acid compositions. Fatty acid composition of fish species can be variable depending on factors such as gender, location and environmental conditions (Özoğul et al., 2007). Therefore different fish species should be preferred in diets. It is also important for consumers that the product is nutritionally balanced as well as economical.

In today's society, many fish consumers generally prefer culture fish such as trout, sea bream, and sea bass. The most important reason for this is that these fish are constantly present in the market. A lot of studies have been made on the nutritional profiles of fish (Bayraklı \& Duyar, 2019; Iaconisi et al., 2018; Tekle et al., 2013; Tidball et al., 2017; Turchini et al., 2018). Although, byproducts of fish such as skin are not well known by consumers due to not being sold by fish markets there is important studies about fatty acid levels of some fish skins. Cui et al., (2018) reported that total fatty acid concentrations of some sea fish skins were changed 3.6$156 \mathrm{mg} / \mathrm{g}$ wet weight and Nijinkoue et al.,2002 found important fatty acids on Sardinella maderensis, Sardinella aurita and Cephalopholis taeniops skins. These studies show that waste fish skins have significant fatty acid levels. Although there are lots of studies that have pointed to fatty acid profiles of trout (Yavuzer et al., 2020), sea bream (Erkan \& Özden, 2007) and sea bass (Bouaziz et al., 2017) there is few information on the fatty acid profile of waste skins of these. Thus, the aim of this study was to evaluation of fish by-products and increasing the economic value of fish skin and determine the fatty acid profiles of skin and their utilization as skin crackers based on consumer perception.

\section{MATERIAL AND METHOD}

Fish Samples and Obtaining Fish Crackers: Rainbow trout (Oncorhynchus mykiss 300 \pm 30 gr), sea bream (Sparus aurata $380 \pm 15 \mathrm{gr}$ ) and sea bass (Dicentrarchus labrax $360 \pm 12 \mathrm{gr}$ ) were purchased from the local fish markets in Adana, Turkey. For all analyzes of the study, 9 $\mathrm{kg}$ rainbow trout, $11 \mathrm{~kg}$ bream and $12 \mathrm{~kg}$ sea bass were used. Fish were 1 day post-capture on arrival at the laboratory in ice with polystyrene boxes. Fish-to-ice ratio was 1:1 (w/w). In sterile laboratory conditions, the fish were gutted and the scales of sea bream and sea bass were cleaned and their skin was manually separated from the meat with a kitchen knife. $\% 9.2$ skin was obtained from rainbow trout, \%8.6 from sea bream and $\% 8.2$ from sea bass.

The skins were cut long and thin to obtain crackers from fish skin. Only wheat flour (\%3) was added to the fish skin by rolling and fried in sunflower oil $\left(200^{\circ} \mathrm{C}\right)$ for 3 minutes. After the frying process crackers were cooled in the room conditions. They were then transferred to the refrigerator $\left(3 \pm 1^{\circ} \mathrm{C}\right)$ in stretch filmed plate for sensory and microbial analysis. 90 crackers were made from each fish species and arranged in a maximum of 15 on the plates to avoid overlapping. Sensory and microbiological analyzes were performed on the $0,3,5,7,10$ and $12^{\text {th }}$ days of storage.

Fatty Acid Analysis: Lipid analysis was performed according to the method of Bligh \& Dyer (1959). Extracted lipid, fatty acids methyl esters were performed according to the method of Ichihara et al. (1996) with minor modifications. $4 \mathrm{~mL}$ of $2 \mathrm{M} \mathrm{KOH}$ and $2 \mathrm{~mL}$ of $\mathrm{n}$-heptane were added to $25 \mathrm{mg}$ of extracted oil sample. It was then vortexed for 2 minutes at room temperature and centrifuged at $4000 \mathrm{rpm}$ for 10 minutes at $4{ }^{\circ} \mathrm{C}$ and the heptane layers were taken up for gas chromatography (GC) analysis.

Microbiological analysis: Although frying processing destroys existing microorganisms in fish skin, microbiological analyzes were performed to determine the bacterial load that may occur during storage. Triplicate samples were taken for total Enterobacteriaceae, total aerobic mesophilic (TAMB), total aerobic psychrophilic bacteria (TAPB), Escherichia coli (Thompson et al., 1990) and Staphylococcus aureus (Schoeller and Ingham, 2001) counts. $90 \mathrm{ml}$ of sterile Ringer solution (1/4 strength) to 10 $\mathrm{g}$ of fish muscle was mixed with and then Stomached (Masticator Nr S18/420, IUL Instruments, Barcelona, Spain) for $3 \mathrm{~min}$. More decimal dilutions were made, and then 0.1 $\mathrm{ml}$ of each dilution was pipetted onto the face of plate count agar (Fluka 70152, Steinheim, Switzerland) plates in triplicate. Table 1 shows the bacteria groups and their plates. In the study, microbiological analyzes were done on fried fish crackers. 
Table1. Plates and methods used for microbiological analysis.

\begin{tabular}{lll}
\hline Microorganism & Plate & Incubation time \\
\hline TAMB & Plate count agar (PCA) & $30^{\circ} \mathrm{C} 72$ hours \\
TAPB & Plate count agar (PCA) & $6^{\circ} \mathrm{C} 10$ days \\
Enterobacteriaceae & Violet Red Bile Agar & $37^{\circ} \mathrm{C} 24$ hours \\
E. coli & MUG added Mac Conkey Agar & $30^{\circ} \mathrm{C} 24$ hours \\
S. aureus & Baird Parker Agar & $37^{\circ} \mathrm{C} 24-48$ hours \\
\hline
\end{tabular}

Sensory Analysis: Sensory evaluation for fried fish skin crackers was carried out according to the method of Paulus et al., 1979. The hedonoic scale used for fried fish skins is given in Table 2. The opinions of the panelist were assessed (12 men and 32 women with different geographical regions) for color, odour, flavor, texture and general acceptability scored to the given pages using 9-point hedonic scale (1 excessively dislike, 9 excessively like). Analyses were done in day conditions on each storage days by the staff members and 4th semester students of the Kırşehir Ahi Evran University/Turkey, Food Processing Department who are familiar with fresh fish.

Table2. The hedonoic scale used for fried fish skins.

\begin{tabular}{|c|c|c|c|c|c|c|c|c|c|}
\hline & $\begin{array}{l}\overrightarrow{0} \\
8 \\
0 \\
3 \\
0 \\
0 \\
0\end{array}$ & $\begin{array}{l}\overrightarrow{0} \\
\stackrel{0}{0} \\
0 \\
0 \\
0 \\
\infty \\
\infty\end{array}$ & $\begin{array}{l}\overrightarrow{0} \\
\stackrel{0}{\sim} \\
\stackrel{r}{r}\end{array}$ & 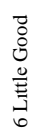 & 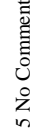 & 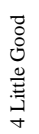 & $\begin{array}{l}\overrightarrow{\tilde{g}} \\
\text { m }\end{array}$ & 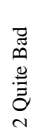 & 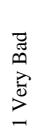 \\
\hline $\begin{array}{l}\text { Color } \\
\text { Oudor } \\
\text { Flavor } \\
\text { Texture } \\
\text { General } \\
\text { Acceptability }\end{array}$ & & & & & & & & & \\
\hline
\end{tabular}

Statistical Analysis: SPSS 22 version software (Chicago, Illinois, USA) used for one-way variance analysis (ANOVA) and Duncan's Multiple Range Test. Calculations were done in triplicate and comparisons at a p-value of $<0.05$ were carried out to point out significant differences.

\section{RESULTS AND DISCUSSION}

Figure 1 shows the sensory analyses of crackers obtained by rainbow trout, sea bream, and sea bass skins during storage. At the beginning of storage, all groups were close to 9 and off-flavors and off-odors were not detected. In the following storage days, the G1 group was separated from the other groups in terms of color, odor, taste and texture parameters. G2 and G3 groups were rejected in terms of general acceptability on the 10th day of storage, while G1 group did not have any rejection points (bigger than 4).

No coliform, E. coli and $S$. aureus were found in fish crackers during storage. However, TAMB and TAPB numbers tended to increase. Figure 2 shows the total mesophilic aerobic and psychrotrophic aerobic bacteria counts.

The increasing of mesophilic aerobic bacteria in the G3 was higher than the G1 and G2. G1, a freshwater fish byproduct, showed a lower microbiological increase than other groups. For G1, the colony number was over 30 colony only on day 10th day of storage.

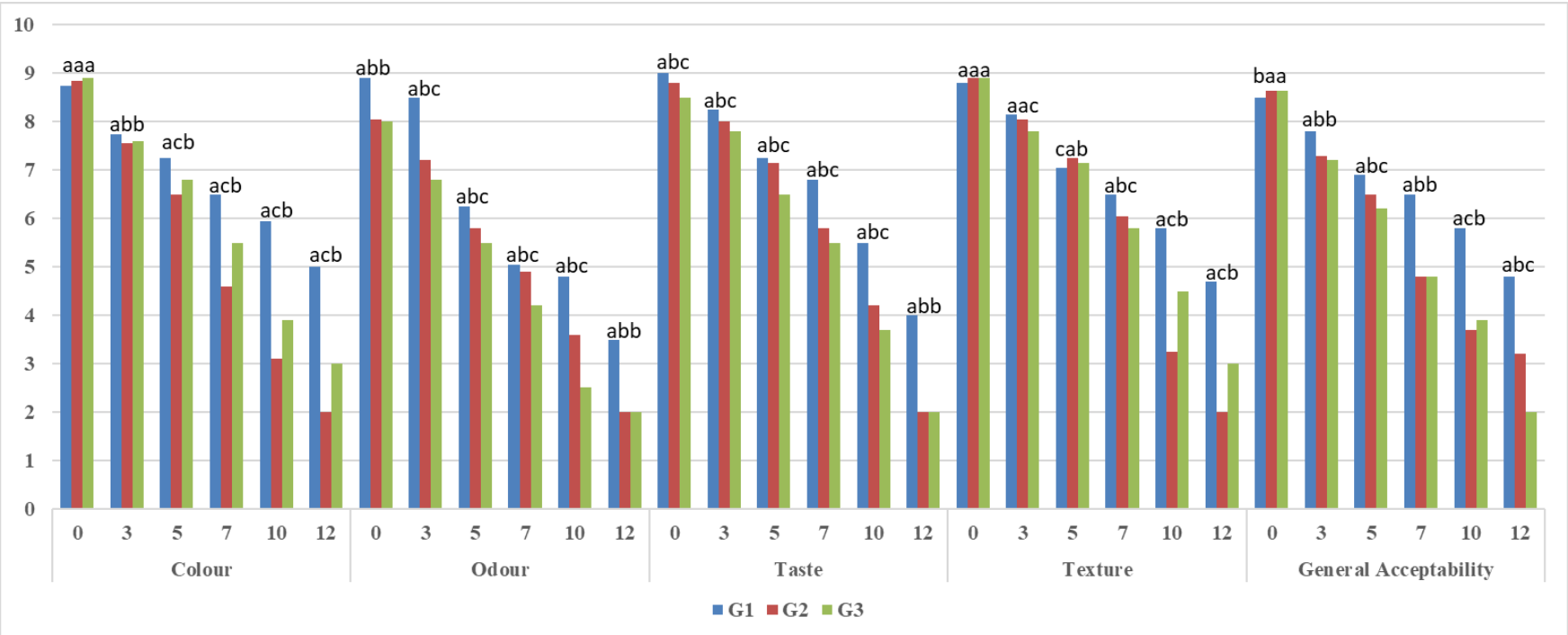

Figure 1. Sensorial changes of cooked crackers during storage. Different letters $(a-c)$ in the same column show significant differences $(p$ $<0.05)$.

It is known that gram negative psychrotrophic bacteria cause the degradation of aerobically stored fresh fish at cold temperatures (Sallam, 2007). Initial TAPB counts were below dedection limit for all groups until the 5th day. The highest value was $3.52 \mathrm{log} \mathrm{CFU} / \mathrm{g}$ for G2 group on 12th day of storage. TAPB values of groups were
$2.58 \log \mathrm{CFU} / \mathrm{g}, 2.57 \log \mathrm{CFU} / \mathrm{g}$ and $2.44 \mathrm{log} \mathrm{CFU} / \mathrm{g}$ respectively on the 10th day of storage, where the G2 and G3 groups were sensually rejected. When sensory and microbiology data are analyzed at the same time, it is seen that $\mathrm{G} 1$ group performs better on all storage days. (Kaba et al., 2012) reported that the TAMB number did not exceed 
$5.29 \log \mathrm{CFU} / \mathrm{g}$ and the TAPB number was below $10^{-1}$ during storage in garfish meatballs which fried in sunflower oil after smoking. (Keser and İzci, 2020) reported that TAMB and TAPB values of meatballs made from rainbowtrout meat exceeded $7 \log \mathrm{CFU} / \mathrm{g}$ level on the $7^{\text {th }}$ day of storage in the control group. In the present study, TAMB and TAPB numbers of all groups did not exceed $3.52 \log \mathrm{CFU} / \mathrm{g}$ during storage.

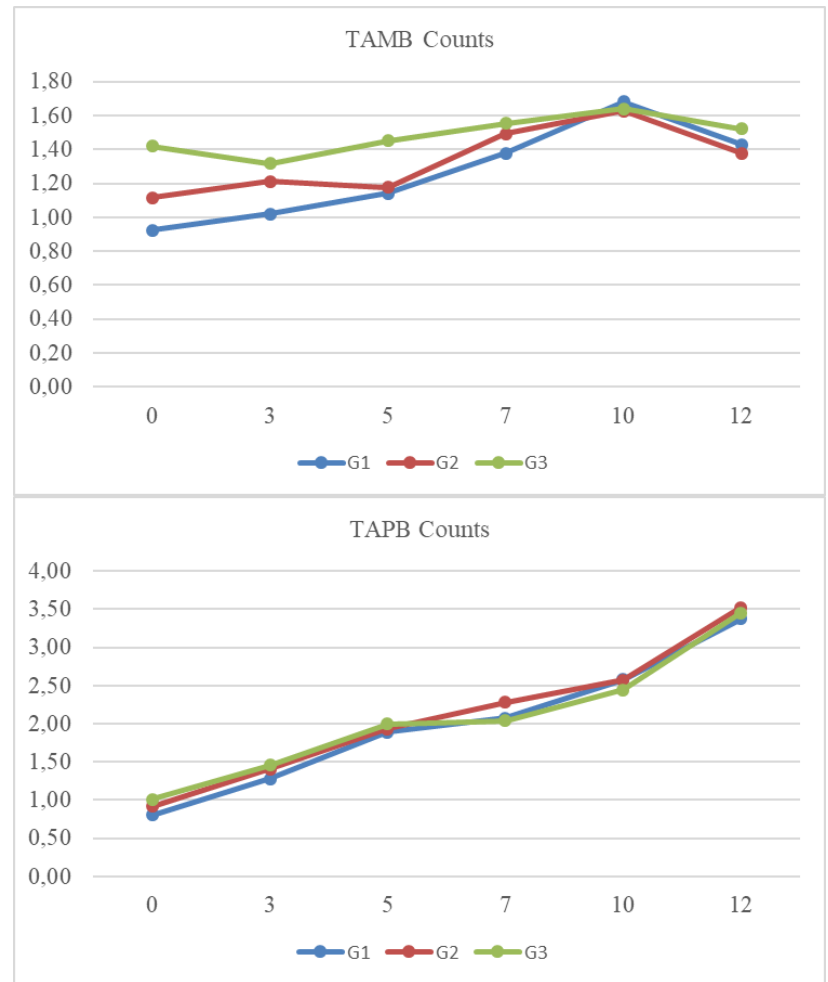

Figure 2. Changes in the counts of mesophilic and psychrophilic bacteria of crackers during storage at $3 \pm 1 \mathrm{C}^{\circ}$ $(\log \mathrm{CFU} / \mathrm{g})$.

Table 3 shows the $\%$ as a mean value of 27 fatty acids for three groups. The fatty acid compositions of groups were 21.56-24.59\% (SFA), 41.43-45.18\% (MUFAs) and 28.06-29.48\% (PUFAs). Fatty acids occurring in the highest rates were myristic acid (C14:0, 2.22-2.78\%), palmitic acid (C16:0, 11.72-14.04\%), palmitoleic acid (C16:1, 3.50-4.68\%), stearic acid (C18:0, 2.95-3.58\%), oleic acid (C18:1n9 cis, 30.89-34.17\%), linoleic acid (C18:2n6, 13.97-17.35\%), EPA, (C20:5n3, 2.20-2.96\%) and DHA, (C22:6n3, 4.09-5.86\%).

Rainbow trout skin which had higher sensorial points was very rich in n-3 (PUFAs / 28.06\%) like sea bream $(29.48 \%)$ and sea bass $(29.03 \%)$. These values are similar with our previous study (Özoğul et al., 2013) obtained with rainbow trout meat. The levels of SFAs between groups did not vary. PUFA/SFA value was found as 1.14 for G1, 1.39 for G2 and 1.32 for G3. These values are higher than the minimum value of PUFA/SFA recommended as 0.45 (HMSO, 1994). Palmitic acid (C16:0) was the primary SFA acid contributing $11.72 \%$,
$13.79 \%$ and $14.04 \%$ of the total SFA content of lipids of rainbow trout, sea bream, and sea bass skins, respectively. Oleic acid (C18:1n-9) was the primary MUFAs accounting for $34.17 \%$ of total fatty acids for G1 while it contributes $30.86 \%$ of total fatty acids for G2 and $32.39 \%$ for G3. Moreover, the level of oleic acid was significantly $(p>0.05)$ higher for G1 group than others. But the level of linoleic acid (C18:2n6) was significantly lower for G1 with value of $13.97 \%$ while G2 and G3 had $17.35 \%$ and $16.76 \%$ linoleic acid. Our previous study (Özoğul et al., 2013) found the oleic acid value as $30.47 \%$ in trout muscle. In fact, this value is close to the G1 group found in the current study for fish skin. On the other hand (Cui et al., 2018) reported that the total polyunsaturated fatty acid concentrations were higher in skin than muscle for some fish species.

Table 3. Fatty acid contents of rainbow trout, sea bream and sea bass skins (\%).

\begin{tabular}{|c|c|c|c|}
\hline FA & G1 $\overline{\mathbf{x}} \pm$ Sd & G1 $\overline{\mathbf{x}} \pm$ Sd & $\mathbf{G 1} \overline{\mathbf{x}} \pm$ Sd \\
\hline C12:0 & $5.74 \pm 0.02^{\mathrm{a}}$ & $0.05 \pm 0.01^{\mathrm{b}}$ & $0.03 \pm 0.00^{\mathrm{b}}$ \\
\hline C14:0 & $2.22 \pm 0.05^{\mathrm{b}}$ & $2.78 \pm 0.07^{\mathrm{a}}$ & $2.34 \pm 0.01^{\mathrm{b}}$ \\
\hline C15:0 & $0.14 \pm 0.08^{\mathrm{a}}$ & $0.22 \pm 0.00^{\mathrm{a}}$ & $0.20 \pm 0.00^{\mathrm{a}}$ \\
\hline C16:0 & $11.72 \pm 0.31^{\mathrm{b}}$ & $13.79 \pm 0.28^{\mathrm{a}}$ & $14.04 \pm 0.02^{\mathrm{a}}$ \\
\hline C17:0 & $0.22 \pm 0.06^{\mathrm{a}}$ & $0.33 \pm 0.02^{\mathrm{a}}$ & $0.26 \pm 0.01^{\mathrm{a}}$ \\
\hline C18:0 & $3.58 \pm 0.23^{\mathrm{a}}$ & $2.95 \pm 0.08^{b}$ & $3.06 \pm 0.02^{\mathrm{b}}$ \\
\hline C20:0 & $0.17 \pm 0.07^{\mathrm{a}}$ & $0.25 \pm 0.01^{\mathrm{a}}$ & $0.22 \pm 0.00^{\mathrm{a}}$ \\
\hline C22:0 & $0.57 \pm 0.07^{\mathrm{a}}$ & $0.61 \pm 0.01^{\mathrm{a}}$ & $0.50 \pm 0.02^{\mathrm{a}}$ \\
\hline C24:0 & $0.25 \pm 0.04^{b}$ & $0.31 \pm 0.01^{\mathrm{b}}$ & $1.31 \pm 0.00^{\mathrm{a}}$ \\
\hline$\sum$ SFA $^{*}$ & $24.59 \pm 0.35^{\mathrm{a}}$ & $21.27 \pm 0.28^{\mathrm{b}}$ & $21.94 \pm 0.01^{\mathrm{b}}$ \\
\hline C14:1 & $0.03 \pm 0.00^{c}$ & $0.13 \pm 0.00^{\mathrm{a}}$ & $0.10 \pm 0.00^{\mathrm{b}}$ \\
\hline C15:1 & $0.04 \pm 0.03^{\mathrm{a}}$ & ND & ND \\
\hline C16:1 & $3.50 \pm 0.1^{\mathrm{c}}$ & $4.68 \pm 0.05^{\mathrm{a}}$ & $4.04 \pm 0.0^{\mathrm{b}}$ \\
\hline C17:1 & $0.05 \pm 0.03^{\mathrm{a}}$ & $0.03 \pm 0.00^{\mathrm{a}}$ & $0.03 \pm 0.00^{\mathrm{a}}$ \\
\hline C18:1n9 & $34.17 \pm 0.45^{\mathrm{a}}$ & $30.89 \pm 0.30^{\mathrm{c}}$ & $32.39 \pm 0.16^{\mathrm{b}}$ \\
\hline C18:1n7 & $3.47 \pm 0.11^{\mathrm{a}}$ & $3.54 \pm 0.21^{\mathrm{a}}$ & $3.50 \pm 0.00^{\mathrm{a}}$ \\
\hline C20:1n9 & $3.45 \pm 0.43^{\mathrm{a}}$ & $1.84 \pm 0.02^{\mathrm{c}}$ & $2.35 \pm 0.01^{\mathrm{b}}$ \\
\hline C22:1n9 & $0.46 \pm 0.01^{\mathrm{a}}$ & $0.30 \pm 0.00^{\mathrm{c}}$ & $0.42 \pm 0.00^{\mathrm{b}}$ \\
\hline C24:1n9 & $0.02 \pm 0.00^{\mathrm{a}}$ & $0.03 \pm 0.00^{\mathrm{a}}$ & $0.02 \pm 0.00^{\mathrm{a}}$ \\
\hline$\sum$ MUFA $^{* *}$ & $45.18 \pm 0.26^{\mathrm{a}}$ & $41.43 \pm 0.01^{\mathrm{c}}$ & $42.85 \pm 0.16^{b}$ \\
\hline C18:2 n6 & $13.97 \pm 0.76^{\mathrm{b}}$ & $17.35 \pm 0.27^{\mathrm{a}}$ & $16.76 \pm 0.06^{\mathrm{a}}$ \\
\hline C18:3 n6 & $0.16 \pm 0.04^{\mathrm{a}}$ & $0.13 \pm 0.01^{\mathrm{a}}$ & $0.10 \pm 0.00^{\mathrm{a}}$ \\
\hline C18:3 n3 & $4.01 \pm 0.06^{\mathrm{a}}$ & $3.54 \pm 0.08^{\mathrm{b}}$ & $3.53 \pm 0.04^{b}$ \\
\hline $\mathrm{C20}: 2$ cis & $0.22 \pm 0.05^{\mathrm{a}}$ & $0.22 \pm 0.00^{\mathrm{a}}$ & $0.14 \pm 0.00^{\mathrm{a}}$ \\
\hline C20:3n6 & $0.40 \pm 0.03^{\mathrm{a}}$ & $0.37 \pm 0.00^{\mathrm{ab}}$ & $0.32 \pm 0.00^{\mathrm{b}}$ \\
\hline C20:4n6 & $1.18 \pm 0.06^{\mathrm{a}}$ & $0.75 \pm 0.00^{c}$ & $0.99 \pm 0.01^{\mathrm{b}}$ \\
\hline C20:5 n3 & $2.20 \pm 0.02^{\mathrm{b}}$ & $2.90 \pm 0.01^{\mathrm{a}}$ & $2.96 \pm 0.04^{\mathrm{a}}$ \\
\hline C22:2 cis & $0.09 \pm 0.05^{\mathrm{a}}$ & $0.15 \pm 0.01^{\mathrm{a}}$ & $0.10 \pm 0.01^{\mathrm{a}}$ \\
\hline C22:6 n3 & $5.86 \pm 0.20^{\mathrm{a}}$ & $4.09 \pm 0.13^{\mathrm{b}}$ & $4.14 \pm 0.10^{\mathrm{b}}$ \\
\hline$\sum$ PUFA $^{* * *}$ & $28.06 \pm 0.71^{\mathrm{a}}$ & $29.48 \pm 0.23^{\mathrm{a}}$ & $29.03 \pm 0.25^{\mathrm{a}}$ \\
\hline PUFA/SFA & $1.14 \pm 0.05^{b}$ & $1.39 \pm 0.03^{\mathrm{a}}$ & $1.32 \pm 0.01^{\mathrm{a}}$ \\
\hline$\sum \omega 3$ & $12.06 \pm 0.11^{\mathrm{a}}$ & $10.52 \pm 0.04^{\mathrm{b}}$ & $10.63 \pm 0.18^{b}$ \\
\hline$\sum \omega 6$ & $15.70 \pm 0.83^{b}$ & $18.60 \pm 0.28^{\mathrm{a}}$ & $18.17 \pm 0.06^{\mathrm{a}}$ \\
\hline $\bar{\sum} \omega 6 / \sum \omega 3$ & $1.27 \pm 0.04^{\mathrm{b}}$ & $1.77 \pm 0.03^{\mathrm{a}}$ & $1.71 \pm 0.02^{\mathrm{a}}$ \\
\hline DHA & $5.86 \pm 0.20^{\mathrm{a}}$ & $4.09 \pm 0.13^{\mathrm{b}}$ & $4.14 \pm 0.10^{\mathrm{b}}$ \\
\hline EPA & $2.20 \pm 0.02^{\mathrm{b}}$ & $2.90 \pm 0.01^{\mathrm{a}}$ & $2.96 \pm 0.04^{\mathrm{a}}$ \\
\hline DHA/EPA & $2.67 \pm 0.12^{\mathrm{a}}$ & $1.41 \pm 0.05^{\mathrm{b}}$ & $1.40 \pm 0.02^{\mathrm{b}}$ \\
\hline
\end{tabular}

Among the analyzed fish species, the highest DHA (C22:6n3) was obtained from G1, with value of $5.86 \%$ while $\mathrm{G} 2$ and G3 had 4.09 and $4.14 \%$ of DHA. While the DHA value for G1 was lower than the level of $10.29 \%$ found in trout meat (Özoğul et al., 2013), G2 and G3 were found to be close to sea bream (Magalhães et al., 2020) and sea bass (Betancor et al., 2020) meat. But EPA 
was significantly ( $p>0.05$ ) higher in $\mathrm{G} 2$ and $\mathrm{G} 3$ groups than G1. It is known that EPA and DHA values of catched fish species can be higher than cultured fish species (Chen et al., 1995; Rahman et al., 1995). EPA is the most important essential fatty acid among the $\mathrm{n} 3$ series fatty acids for the human diet (Chen et al., 1995) and also DHA decreases the concentration of low-density lipoprotein cholesterol in plasma (Childs et al., 1990). Differences in fatty acids of rainbow trout, sea bream, and sea bass should not only be considered with respect to species habitat but also based on their natural diet. Although the species that analyzed in this study can be separated as marine and freshwater, it is known that all of them are culture fish. That is, all groups had fed with ready pellet feeds. Therefore, although there is a statistical difference between some parameters, fatty acid values are very close to each other. The highest sensorial score and EPA ratio in the G1 group indicate that rainbow trout skin is quite suitable for cracker production. However, the high level of omega 3 series fatty acids of fish skins usually discarded during consumption is thought-provoking in terms of consumption habits.

Among the groups, the highest ratio of $\mathrm{n} 6 / \mathrm{n} 3$ was found to be 1.77 for G2 followed by 1.71 for G3 and 1.30 for $\mathrm{G} 1$. The ratios of $\mathrm{n} 6 / \mathrm{n} 3$ found in this study were lower in G1, G2, and G3 than the maximum value of 4.0 recommended by the UK Department of Health (HMSO, 1994). Simopoulos (2010) reported that a ratio of $1: 1$ to $2: 1$ $\omega 6 / \omega 3$ fatty acids should be the ideal for human health. Also, DHA/EPA ratio was significantly higher in G1 (2.67\%) than G2 (1.41\%) and G3 (1.40\%). When the fatty acids and sensory analysis results are evaluated together, it is seen that the fish skin which is in the waste state during the canning and cooking processes, is an important source of fatty acids. Furthermore, trout skin can be said to have great potential in cracker production compared to the groups analyzed in this study. On the other hand cooking over $100^{\circ} \mathrm{C}$ damages omega 3 fatty acids and the degree of damage is known to vary with the time exposed to heat (Furnier et al., 2006). Therefore, methods should be worked on to increase the cooking time and reduce the temperature.

\section{CONCLUSION}

In this study, fatty acid profiles of raw fish skins were determined and the sensory and microbiological levels of the skins after frying process were analyzed. Even the panelists who do not normally consume fish liked the taste of fish crackers. According to current study results, although they have very important fatty acids, fish skins are seen as byproduct materials during processing or cooking. Study data will contribute to the transformation of fish by-products into industrial products.

\section{CONFLICT OF INTEREST} interests.

The authors declare that they have no competing

\section{REFERENCES}

Bayraklı, B. \& Duyar, H.A. (2019). Karadeniz'de Farklı Hammaddelerden Elde Edilen Balık Unlarının Besin Kompozisyonu. Journal of Anatolian Environmental and Animal Sciences,4(3), 545550. DOI: 10.35229/jaes.636806

Betancor, M.B., MacEwan, A., Sprague, M., Gong, X., Montero, D., Han, L., Napier, J.A., Norambuena, F., Izquierdo, M. \& Tocher, D.R. (2021). Oil from transgenic Camelina sativa as a source of EPA and DHA in feed for European sea bass (Dicentrarchus labrax L.). Aquaculture, 530, 735-759.

Bligh, E.C. \& Dyer, W.J. (1959). A rapid method of total lipid extraction and purification. Canadian Journal of Biochemistry and Physiology, 37, 913917.

Bouaziz, M., Bejaoui, S., Rabeh, I., Besbes, R., El, R., Cafsi, M. \& Falcon, J. (2017). Impact of temperature on sea bass, Dicentrarchus labrax, retina: Fatty acid composition, expression of rhodopsin and enzymes of lipid and melatonin metabolism. Experimental Eye Research, 159, 8797.

Chen, I.C., Chapman, F.A., Wei, C.I., Porteir, K.M. \& O"Keefe, S.F. (1995). Differentiation of cultured and wild sturgeon (Acipencer oxyrinchus desotoi) based on fatty acid composition. Journal of Food Science, 60, 631-635.

Childs, M.T., King, I.B. \& Knopp, R.H. (1990). Divergent lipoprotein responses to fish oils with various ratios of eicosapentaenoic and docosahexaenoic acids. The American Journal of Clinical Nutrition, 52, 632-639.

Conner, W.E. (2000). Importance of n-3 fatty acids in health and disease. The American Journal of Clinical Nutrition, 17, 171S-175S.

Cui, L., Wang, S., Yang, X., Gao, L., Zheng, M., Wang, R., Qiao, L. \& Xu, C. (2018). Fatty acids, polychlorinated dibenzo-p-dioxins and dibenzofurans, and dioxin-like polychlorinated biphenyls in paired muscle and skin from fish from the Bohai coast, China: Benefits and risks associated with fish consumption. Science of the Total Environment, 639, 952-960.

Erkan, N. \& Özden, Ö. (2007). The changes of fatty acid and amino acid compositions in sea bream (Sparus aurata) during irradiation process. Radiation Physics and Chemistry, 76, 1636-1641.

Fenton, W.S., Hibbeln, J. \& Knable M. (2000). Essential fatty acids, lipid membrane abnormalities, and the diagnosis and treatment of schizophrenia. Biological Psychiatry, 47, 8-21. 
Furnier, V., Destaillats, F., Juaneda, P., Dionisi, F., Lambelet, P., Sebedio, J.L. \& Bordeaux, $O$. (2006). Thermal degradation of long-chain polyunsatured fatty acids during deodozation of fish oil. European Journal of Lipid Science and Technology, 108, 33-42.

Giudetti, A.M. \& Cagnazzo, R. (2012). Beneficial effects of n-3 PUFA on chronic airway inflammatory diseases. Prostaglandins \& Other Lipid Mediators, 99, 57-67.

HMSO UK. (1994). Nutritional aspects of cardiovascular disease (report on health and social subjects No. 46). London: HMSO.

Iaconisi, V., Bonellia, A., Pupino, R., Gai, F. \& Paris, G. (2018). Mealworm as dietary protein source for rainbow trout: Body and fillet quality traits. Aquaculture, 484, 197-204.

Ichihara, K., Shibahara, A., Yamamoto, K. \& Nakayama, T. (1996). An improved method for rapid analysis of the fatty acids of glycerolipids. Lipids, 31, 535-539.

Kaba, N., Özer Ö. \& Çorapçı B. (2012). Dumanlanmış zargana (Belone belone euxini Günther, 1866) köftelerinin bazı kalite parametrelerinin belirlenmesi. Journal of FisheriesSciences.com, 6, 357-367.

Keser, E., İzci, L. (2020). Gökkuşağı alabalığı (Oncorhynchus mykiss)'ndan elde edilen balık köftelerinde biberiye ve defne uçucu yağlarının mikrobiyolojik ve duyusal kaliteye etkisi. Acta Aquatica Turcica, 16(1), 13-21.

La Rovere, M.T. \& Christensen, J.H. (2015). The autonomic nervous system and cardiovascular disease: role of n-3 PUFAs. Vascular Pharmacology, 71,1-10.

Magalhães, R., Guerreiro, I., Coutinho, F., Moutinho, S., Sousa, S., Delerue-Matos, C., Domingues, V.F., Olsen, R.E., Peres, H. \& Oliva-Teles, A. (2020). Effect of dietary ARA/EPA/DHA ratios on growth performance and intermediary metabolism of gilthead sea bream (Sparus aurata) juveniles. Aquaculture, 516, 734644, DOI: 10.1016/j.aquaculture.2019.734644.

Njinkoue, J.M., Barnathan, G., Miralles, J., Gaydou, E.M. \& Samb, A. (2002). Lipids and fatty acids in muscle, liver and skin of three edible fish from the Senegalese coast: Sardinella maderensis, Sardinella aurita and Cephalopholis taeniops. Comparative Biochemistry and Physiology, 131, 395-402.

Özoğul, Y., Özoğul, F. \& Alagöz, S. (2007). Fatty acid profiles and fat contents of commercially important seawater and freshwater fish species of Turkey. Food Chemistry, 103, 217-223.

Özoğul. F., Yavuzer, E., Özoğul, Y. \& Kuley, E. (2013). Comparative quality loss in wild and cultured rainbow trout (Oncorhynchus mykiss) during chilling storage. Food Science and Technology Research, 19, 445-454.

Paulus, K., Zacharias, R., Robinson, L. \& Geidel, H. (1979). Kritische Betrachtungen zur "Bewetenden
Prufung mit skale" als einem Wesentlichen Verfahren der Sensorichen Analyse. LWT-Food Science and Technology, 12, 52-61.

Rahman, S.A., Huah, T.S., Hassan. \& O, Daud, N.M. (1995). Fatty acid composition of some Malaysian freshwater fish. Food Chemistry, 54, 45-49.

Schoeller, N.P. \& Ingham, S.C. (2001). Comparison of the Baird-Parker agar and 3MTMPetrifilmTMrapid S. aureus count plate methods for detection and enumeration of Staphylococcus aureus. Food Microbiology, 18, 581-587.

Simopoulos, A.P. (1991). Omega-3 fatty acids in health and disease and in growth and development, a review. The American Journal of Clinical Nutrition, 54, 438-463.

Simopoulos, A.P. (2010). The omega-6/omega-3 fatty acid ratio: Health implications. Oilseeds and Fats, Crops and Lipids, 17, 267-275.

Tekle, Ş., Sağdıç, O., Nursaçan, Ş., Yetim, H. \& Erdem, M. (2013.). Halal Food Problems in Our Country and in The World. European Journal of Science and Technology, 1, 1-6.

Thompson, J.S., Hodge, D.S. \& Borczyk, A.A. (1990). Rapid biochemical test to identify verocytotoxinpositive strains of Escherichia coli serotype O157. Journal of Clinical Microbiology, 28, 2165-2168.

Tidball, M.M., Exler, J., Somanchi, M., Williams, J., Kraft, C., Curtis, P. \& Tidbal, K.G. (2017). Addressing information gaps in wild-caught foods in the US: Brook trout nutritional analysis for inclusion into the USDA national nutrient database for standard reference. Journal of Food Composition and Analysis, 60, 57-63.

Turchini, G.M., Hermon, K.M. \& Francis, D.S. (2018). Fatty acids and beyond: Fillet nutritional characterization of rainbow trout (Oncorhynchus mykiss) fed different dietary oil sources. Aquaculture, 491, 391-397.

Valfré, F., Caprino, F. \& Turchini, G.M. (2003). The health benefit of seafood. Veterinary Research Communications, 27, 507-512.

Ward, O.P. \& Singh, A. (2005). Omega-3/6 fatty acids: alternative sources of production. Process Biochemistry, 40, 3627-3652.

Yavuzer, E. (2018). Development of defective fish egg sorting machine with colour sensor for trout facilities. Aquaculture Research, 49, 3634-3637.

Yavuzer, E. (2020). Comparing the fatty acid level of sand smelt (Atherina boyeri) with rainbow trout (Oncorhynchus mykiss) as a cheaper protein and fatty acid source. Acta Aquatica Turcica, 16(1), 106-112. DOI: $10.22392 /$ actaquatr.603538

Zhu, Y., Tan, Q., Zhang, L., Yao, J., Zhou, H., Hu, P., Liang, X. \& Liu, H. (2019). The migration of docosahexenoic acid (DHA) to the developing ovary of female zebrafish (Danio rerio). Comparative Biochemistry and Physiology Part A: Molecular \& integrative physiology, 233, 97105. 